\title{
Antimicrobial activity and acute and chronic toxicity of the essential oil of Lippia origanoides ${ }^{1}$
}

\author{
Viviane A. Andrade ${ }^{2}$, Anna C. Almeida ${ }^{3}$, Dayane S. Souza ${ }^{3}$, Keila G.F. Colen ${ }^{3}$, Auricélio \\ A. Macêdo ${ }^{4}$, Ernane R. Martins ${ }^{3}$, Francine S.A. Fonseca ${ }^{3}$ and Renato L. Santos ${ }^{4 *}$ \\ ABSTRACT.- Andrade V.A., Almeida A.C., Souza D.S., Colen K.G.F., Macêdo A.A., Martins E.R., \\ Fonseca F.S.A. \& Santos R.L. 2014. Antimicrobial activity and acute and chronic toxicity \\ of Lippia origanoides. Pesquisa Veterinária Brasileira 34(12):1153-1161. Laboratório de Pa- \\ tologia Molecular, Escola de Veterinária, Universidade Federal de Minas Gerais, Av. Antônio \\ Carlos 6627, Belo Horizonte, MG 31270-000, Brazil. E-mail: rsantos@vet.ufmg.br \\ Currently, there is a growing interest in medicinal plants, because of an increased demand \\ for alternate therapies. In this study, the antimicrobial activity and toxicity of the essential oil \\ of Lippia origanoides (L. origanoides) were investigated. The essential oil of L. origanoides was \\ extracted by steam-dragging distillation and its constituents were identified by chromatogra- \\ phy coupled with mass spectrometry. Among the 15 compounds identified, the most abundant \\ were carvacrol (29.00\%), o-cymene (25.57\%), and thymol methyl ether (11.50\%). The essen- \\ tial oil was studied in antimicrobial assays to determine the MIC and MBC. The results indica- \\ ted that a concentration of $120 \mu \mathrm{L} / \mathrm{mL}$ of oil was sufficient to inhibit the growth of the following \\ microorganisms: Escherichia coli (ATCC 25922), Staphylococcus aureus (ATCC 25923) and Sal- \\ monella cholerasuis (ATCC 10708). Acute and chronic toxic effects of orally administered oil \\ were investigated in Wistar rats by using standard methods. Doses of 30, 60 and $120 \mathrm{mg} / \mathrm{kg}$ of \\ the essential oil did not induce significant changes in weight, behavior or hematological and \\ biochemical parameters in the animals. There were no signs of any histopathological changes \\ to the liver, kidneys or heart of the treated rats, suggesting that Lippia origanoides oil is non- \\ -toxic after oral administration in acute or chronic toxicity studies. The results obtained in this \\ study show that the essential oil of $L$. origanoides has a high safety margin, with no detectable \\ toxic effects in rats treated with doses to $120 \mathrm{mg} / \mathrm{kg}$. In addition, L. origanoides oil demons- \\ trated potent antimicrobial activity against S. aureus, E. coli and S. cholerasuis. Based on these \\ findings, this essential oil may have practical application as a veterinary antimicrobial.
}

INDEX TERMS: Lippia origanoides, essential oil, antimicrobial, acute toxicity, chronic toxicity.

RESUMO-- [Atividade antimicrobiana, toxicidade aguda e crônica do óleo essencial de Lippia origanoides.] Atualmente nota-se um aumento do interesse pelas plantas medicinais, fruto da grande procura por terapias alternativas. Neste trabalho foi avaliada a atividade antimicro-

\footnotetext{
${ }^{1}$ Received on April 29, 2014.

Accepted for publication on July 21, 2014.

${ }^{2}$ Pós-doutoranda do Instituto Educacional Santo Agostinho, Faculdade de Saúde e Desenvolvimento Humanos, Universidade Federal de Minas Gerais (UFMG), Campus Montes Claros, Av. Osmane Barbosa 937, JK, Montes Claros, MG 394004-006, Brazil.

${ }^{3}$ Instituto de Ciências Agrárias, UFMG, Campus Montes Claros, Avenida Universitária 1000, Montes Claros, MG 39404-547. E-mail: annachristina dealmeida@gmail.com

${ }^{4}$ Laboratório de Patologia Molecular, Escola de Veterinária, UFMG, Av. Antônio Carlos 6627, Belo Horizonte, MG 31270-000, Brazil. *Corresponding author: rsantos@vet.ufmg.br
}

biana e a toxicidade do óleo essencial da Lippia origanoides (alecrim-pimenta). 0 óleo essencial de alecrim-pimenta foi obtido por arraste com vapor d'água e seus constituintes foram identificados por cromatografia acoplada a espectrofotômetro de massa (GC/MS). Entre os 15 compostos identificados os mais abundantes foram o carvacrol (29\%), o-cimeno $(25,57 \%)$ e metil timol éter $(11,50 \%)$. Os óleos foram submetidos a ensaios antimicrobianos para determinação da CIM e da CBM. Os resultados mostraram que a dose de $120 \mu \mathrm{l} / \mathrm{mL}$ de qualquer um dos óleos testados foi eficiente em inibir o crescimento dos micro-organismos Escherichia coli (ATCC 25922), Staphylococcus aureus (ATCC 25923) e Salmonella cholerasuis (ATTCC 10708). Os efeitos tóxicos agudos e crônicos foram verificados em animais segundo método de classes - Toxicidade aguda oral (dose fixas) - OECD 420. As concentrações de 30, 60 
e $120 \mathrm{mg} / \mathrm{kg}$ de óleo essencial não induziram alterações significativas no peso, no comportamento dos animais e nem nos parâmetros hematológicos e bioquímicos. Também não houve presença de alterações histopatológicas no fígado, rins e coração sugerindo que o óleo de alecrim-pimenta é atóxico após administração oral em condições agudas ou crônicas. Os resultados obtidos neste trabalho levam a concluir que o óleo essencial de alecrim-pimenta possui uma margem elevada de segurança, com efeitos tóxicos inexistentes além de apresentar atividade antimicrobiana eficaz contra os micro-organimos $S$. aureus, E. coli e S. cholerasuis. Sua utilização na medicina veterinária deve ser considerada como uma grande viabilidade econômica e sustentável.

TERMOS DE INDEXAÇÃO: Lippia origanoides, alecrim-pimenta, óleo essencial, antimicrobiano, toxicidade aguda, toxicidade crônica.

\section{INTRODUCTION}

Owing to the current widespread and frequent use of synthetic antimicrobials, there has been an increase in the resistance of microorganisms to these compounds. Because of this problem, there is an increasing need to find new products with antimicrobial activity, including alkaloids and terpenes, which are present in some vegetables. Medicinal plants and plant-derived essential oils have proven inhibitory and antiseptic activity, and may have potential for application in the field of public health, industry and treatment of animals. There is increasing interest in medicinal plants as well as their active ingredients, which may possess antibiotic properties.

Brazil has the richest plant diversity in the world, with approximately $22 \%$ of the planet's biodiversity and more than 55,000 catalogued species of plants, among an estimated total of 350,000 to 550,000 species (Gatyas \& Savage 2010). The National Program for Medicinal Plants and Phytotherapics published the National List of Medicinal Plants of Interest to the unified health system of Brazil (Sistema Único de Saúde or SUS) in January 2009. In this list, medicinal plants that can potentially produce products of interest to the SUS are listed. Lippia origanoides as among the species listed (Brasil 2006).

Lippia origanoides Cham. (Verbanaceae) is a wild shrub native to the semiarid regions of Brazil. Its leaves are frequently used in phytotherapy. L. origanoides contains $4.5 \%$ of an essential oil incredibly rich in thymol, one of the main active ingredients extracted by steam-dragging distillation (Matos 2002). Some other substances in L. origanoides, such as flavonoids and quinones, may contribute to the action of the main active components (Matos 2002).

The antimicrobial effect of $L$. origanoides essential oil has been tested against the Staphylococcus aureus and Escherichia coli isolated from artisanal Minas cheese produced in Brazil (Castro et al. 2011). The results showed the bactericidal activity of the essential oil of $L$. origanoides, suggesting the possibility of its use as an alternative antibacterial agent. Other studies assessed the antimicrobial and antiseptic activity of L. origanoides essential oil on
25 strains of bacteria (coagulase-negative Staphylococcus, coagulase-positive Staphylococcus, esculin-positive Streptococcus, esculin-negative Streptococcus, and Mannheimia haemolytica) isolated from sheep with mastitis in the north region of Minas Gerais (Castro et al. 2011). The antimicrobial activity of the L. origanoides extract was also tested on isolates of $S$. aureus in which inhibition of microbial growth was shown (Oliveira et al. 2006a, 2006b).

In addition, the toxicity of $L$. origanoides essential oil has been assessed. The investigators in these studies did not observe any acute or subchronic toxicity after oral administration (Fontenelle et al. 2007). In another acute toxicity study, this essential oil was shown to have some toxic effects in mice after peritoneal administration (Almeida et al. 2010).

Results with $L$. origanoides oil found in the literature are varied. This may be due to differences in the parts of the plant used, differences in the methods used for extraction, differences in inoculation methods, as well as differences in the analysis of results. There were also physiological variations between plants cultivated and grown under different environmental conditions, which may have contributed to differences in the composition of the extracts and the experimental differences found in the literature.

Therefore, further research on L. origanoides oil is needed to determine the potential of this medicinal plant as a phytotherapeutic product for use in veterinary medicine. So, the aim of this study was to assess the phytochemical composition, the antimicrobial activity, and the toxicity of the essential oil of L. origanoides.

\section{MATERIALS AND METHODS}

Plant collection. Lippia origanoides plants were collected from the reserve at the Institute of Agricultural Sciences (ICA) at Federal University of Minas Gerais (UFMG). The collection areas were recorded with the aid of a global positioning system receiver. Aerial parts of $L$. origanoides plants were collected in the morning and stored in polyethylene bags, protected from moisture, light, heat, insects and contamination by microorganisms. After collection, the material was stabilized and dried at the Laboratory of Medicinal Plants at ICA/UFMG in an oven with forced air circulation and a ventilation system and controlled and constant temperature of $60 \pm 2^{\circ} \mathrm{C}$ (Falkenberget al. 2007).

Essential oils extraction and analysis. The $L$. origanoides essential oil was obtained using the technique steam-dragging distillation in a pilot distiller (Linax ${ }^{\circledR}$, model D20, SP, Brazil). After $3 \mathrm{~h}$ of extraction, the oil was separated from the hydrolyte by liquid-liquid partitioning, removed with a micropipette and stored in sterile amber glass vials under refrigeration $\left(4-8^{\circ} \mathrm{C}\right)$. Analyses were carried out on three different samples of L. origanoides oil based on the month in which the plants were collected: oil 1 was extracted from plants collected in December 2011, oil 2 was extracted from plants collected in March 2012 and oil 3 was extracted from plants collected in May 2012.

The chromatographic analyses were carried out using a gas chromatography system, Agilent Technologies (GC 7890A), coupled with a mass spectrometer detector (MS 5975C) (GC-MS). A HP-5 MS capillary column was used (Agilent Technologies, stationary phase 5\% phenyl and 95\% methylpolysiloxane, 30m x $250 \mu \mathrm{m}$ d.i. $\times 0.25 \mu \mathrm{m}$ thickness of the film). Helium $(99.9999 \%$ purity) was used as the carrier gas, at a rate of $1 \mathrm{~mL} / \mathrm{min}$. The 
split/splitless injector was maintained at $220^{\circ} \mathrm{C}$. The temperature gradient was set from $50^{\circ} \mathrm{C}(2 \mathrm{~min})$ up to $240^{\circ} \mathrm{C}(1 \mathrm{~min})$ at a rate of $3^{\circ} \mathrm{C} / \mathrm{min}$. The sample volume introduced was $1 \mu \mathrm{L}$ in the injection mode with division of flow and a split ratio of 1:10, using a Combi PAL injector. The mass spectrometer was operated with electron ionization at $70 \mathrm{e} \mathrm{V}$ and a quadruple mass analyzer, operated in scan mode (monitoring) between 29 and 550 (m/z). The samples were diluted and injected into the GC-MS and the constituents were identified using a computer program provided by the manufacturer.

Antimicrobial activity assay. The microbial sensitivity test of $L$. origanoides essential oil was performed using the disc-diffusion method adapted from Pinto et al. (2003), for three different microorganisms Escherichia coli (ATCC 25922), Staphylococcus aureus (ATCC 25923) and S. cholerasuis (ATCC 10708). Sterile filter paper discs (Whatman $\mathrm{n} \times 1,6 \mathrm{~mm}$ diameter) were impregnated with $10 \mu \mathrm{L}$ of oil at concentrations of $30 \mu \mathrm{L} / \mathrm{mL}, 60 \mu \mathrm{L} / \mathrm{mL}$ and $120 \mu \mathrm{L} / \mathrm{mL}$. The inoculum of microorganisms was prepared and standardized according to the $0.5 \mathrm{McF}$ arland standards which correspond to $10^{6}$ colony-forming units. The halos were read and measured in millimeters after $24 \mathrm{~h}$ of incubation at $37^{\circ} \mathrm{C}$ by using a pachymeter (Mitunox Instrumentos, SP/Brazil). The tests were carried out in duplicate.

The minimum inhibitory concentration (MIC) and the minimum bactericidal concentration (MBC) were defined according to recommendations by Rios et al. (1988) as the lowest concentrations of oil preventing visible growth of the microorganism subculture. For the MIC test, a solution was prepared with sterile BHI (Brain Heart Infusion) broth. This solution was prepared with $40 \mu \mathrm{L}$ of Tween 80 and the essential oil diluted to give a concentration of $120 \mu \mathrm{L} / \mathrm{mL}$ of $L$. origanoides. From this solution, macrodilution was performed to obtain concentrations of 60 and $30 \mu \mathrm{L} /$ $\mathrm{mL}$ of $L$. origanoides oil. The test was carried out in duplicate for each of the three samples of oil used and the tubes were incubated at $37^{\circ} \mathrm{C}$ for $24 \mathrm{~h}$ in an incubator. The MBC test was carried out as described above, by using an aliquot from the tube contents of the MIC tests that showed no turbidity after $24 \mathrm{~h}$ of incubation, and were streaked on petri dishes containing TSA agar medium. The plates were incubated at $37^{\circ} \mathrm{C}$ for $24 \mathrm{~h}$.

Acute oral toxicity assay. The experimental procedures using animals described in this methodology were approved by the Ethics Committee for Animal Experimentation at UFMG, under Protocol number 034/2008.The method for assessing acute toxicity established by Organization for Economic Co-operation and Development (OECD) (Guideline 420 2001) is a gradual process using groups of animals of the same sex per step.

It was defined by testing the concentrations close to the doses used in the microbiological tests. A single dose of 0 (group 1 - control), 30 (group 2), 60 (group 3) or $120 \mathrm{mg} / \mathrm{kg}$ (group 4) $\mathrm{L}$. origanoides oil was administered by gavage to five fasted Wistar rats. After treatment, all animals remained in the experimental bioterium at UFMG where they were kept under standard conditions with unrestricted access to food and water, a circadian cycle of light for $12 \mathrm{~h}$ and dark for $12 \mathrm{~h}$, and a controlled temperature of $22 \pm 2^{\circ} \mathrm{C}$.

Systematic behavioral observations (hippocratic screening) were made to provide a general measure of the effects of the test substance on the conscious state, general disposition, activity, coordination, reflexes, and effects on the central autonomic nervous systems (Malone \& Robichaud 1962). Parameters (general activity, vocal fremitus, irritability, response to touch, tail squeeze response, contortion, posterior train position, straightening reflex, body tonus, grab strength, ataxia, auricular reflex, corneal reflex, tremors, convulsions, hypnosis, anesthesia, lacrimation, urination, defecation, piloerection, hypothermia, respiration, cyanosis, hyperemia, death) were assessed at $15 \mathrm{~min}, 30 \mathrm{~min}, 1 \mathrm{~h}, 2 \mathrm{~h}, 4 \mathrm{~h}$ and $8 \mathrm{~h}$ after administration and then daily for 14 days.

The animals were weighed on alternate days to monitor weight gain. Samples of about $4 \mathrm{~mL}$ of blood, collected by cardiac puncture were stored in two types of tubes, one with HB anticoagulant (Laborlab ${ }^{\circledR}$ ) to determine the hematological parameters and the other, without anticoagulant, to obtain the serum to assess the biochemical parameters. The hematological analyses were carried out in a specialized laboratory, service provider. The surviving animals were sedated with $80 \mathrm{mg}$ of ketamine $+15 \mathrm{mg}$ of xylazine per kg, injected intraperitoneally, and were considered to be anesthetized by immobility of the body, but with normal respiratory frequency and amplitude. The animals were sacrificed by cervical dislocation. Macroscopic and histopathological analyses of the liver, heart, and lung were performed and these organs were weighed to determine the absolute weights. Relative organ weights were also calculated (relative to body weight).

Chronic oral toxicity test. The study on chronic toxicity of $L$. origanoides oil was carried out based on the OECD fixed dose protocol 452/2001 using single dose level of $120 \mathrm{mg} / \mathrm{kg}$ (since signs of toxicity were not expected at lower doses), and fewer animals were used. The test animals were kept under the same conditions as previously described for the acute toxicity tests. To investigate the chronic toxicity of the L. origanoides essential oil, after 30 days of oral administration, hematological, histopathological and biochemical (serum) parameters were assessed as described by Fontenelle et al. (2007).

The animals were separated into four groups ( $n=5$ per group) and treated with the essential oil of L. origanoides or saline solution (control) orally by gavage. Blood samples were collected on day 0 (one day before administering the essential oil or vehicle) and on days 15 and 30.The serum concentrations of urea, creatinine, glutamic oxaloacetic transaminase (GOT or AST) and glutamic pyruvic transaminase (GPT or ALT) were determined. The blood samples taken on days 0 and 30 were used to determine erythrocyte, and leukocyte counts, hemoglobin, hematocrit and for biochemical analyses. The blood was stored in two types of tubes, as described above. The hematological analyses were performed in an accredited laboratory. The values obtained were compared within and between groups. At the end of the experimental period (30 days) histopathological analyses of the heart, liver and kidneys were performed.

The animals were observed for 30 days, with the animal behavior observed daily, assessing the following parameters: locomotion, behavior, respiration, fur, and skin alterations, eyes, tremors, salivation, diarrhea, lethargy, drowsiness, number of deaths and causes of death. The data were recorded on a monitoring form for each animal. The animals were weighed on alternate days.

For the histopathological analysis, sections of the heart, liver and kidneys were collected and fixed by immersing in a $10 \%$ buffered formaldehyde solution for $24 \mathrm{~h}$, followed by dehydration in increasing concentrations of alcohol, diaphonized in xylol and soaked in paraffin. The sections were cut to $5 \mu \mathrm{m}$ thickness and stained with hematoxylinand eosin (HE) for histopathological analysis. Any damage was assessed according to intensity and was given a score for each tissue: $0=$ no damage, $1=$ discrete damage, $2=$ moderate damage, and $3=$ severe damage.

The results were analyzed using analysis of variance (ANOVA) followed by a post-hoc test. When appropriate, the Student t-test with the Bonferroni adjustment was used for pairwise comparisons. A value of $\mathrm{p}<0.05$ was used to indicate a statistically significant difference. For the histological analyses, the Kruskal-Wallis non-parametric test was performed followed by Dunn's multiple comparison test. All statistical tests were performed using the software Graph Pad Prism (San Diego, CA). 


\section{RESULTS}

The content of sample of essential oil of Lippia origanoides were analyzed using GC-MS is described in Table 1. Fifteen compounds were identified with o-cymene, thymol methyl ether and carvacrol being the compounds present in the highest concentrations in all three oil samples (Table 1). The average concentration of these compounds was $29.0 \%$ for carvacrol, which was the compound present in the highest amount in all the oils, followed by o-cymene $(25.6 \%)$ and thymol methyl ether (11.5\%).

Table 1. Chemical composition of the essential oils in Lippia origanoides

\begin{tabular}{lcccc}
\hline Compound & Oil $1^{\mathrm{a}}(\%)$ & Oil ${ }^{\mathrm{b}}(\%)$ & Oil 3 $^{\mathrm{c}}(\%)$ & Mean (\%) \\
\hline Camphene & 1.389 & 2.360 & 0.721 & 1.49 \\
b-pinene & 2.222 & 1.909 & 2.793 & 2.31 \\
a-terpinene & 1.328 & 1.359 & 1.913 & 1.53 \\
o-cymene & 26.733 & 19.004 & 30.965 & 25.57 \\
Cineole & 2.203 & 0.895 & 1.264 & 1.45 \\
g-terpinene & 5.731 & 7.190 & 8.696 & 7.21 \\
b-linalool & 0.907 & 0.909 & 1.220 & 1.01 \\
Camphor & 1.270 & 3.369 & 0.760 & 1.80 \\
borneol & 0.687 & 1.906 & 0.734 & 1.11 \\
thymolmethylether & 12.778 & 9.121 & 12.610 & 11.50 \\
l-bornyl acetate & 3.220 & 5.204 & 0.556 & 2.99 \\
Thymol & 4.122 & 3.008 & 3.090 & 3.41 \\
Carvacrol & 27.367 & 33.019 & 26.604 & 29.00 \\
b-caryophyllene & 7.803 & 7.881 & 6.561 & 7.42 \\
3-tert-butyl-4- & 2.240 & 2.868 & 1.512 & 2.21 \\
methoxyphenol & & & & \\
& 100 & 100 & 100 & 100
\end{tabular}

a Oil extracted in December 2011, ${ }^{\mathrm{b}}$ Oil extracted in May 2012, ${ }^{\mathrm{c}}$ Oil extracted in March 2012.
The antimicrobial activity of the L. origanoides essential oils was tested against the microorganisms Staphylococcus aureus, Ehcerichia coli, and S. cholerasuis. The disk-diffusion test results are shown in Figure 1. A concentration of $60 \mu \mathrm{L} / \mathrm{mL}$ of L. origanoides (oil number 1 ) had a significant inhibitory effect on the growth of $E$. coli, while only a concentration of $120 \mu \mathrm{L} / \mathrm{mL}$ of oils number 2 and 3 inhibited the growth of this microorganism with a significant difference according to the Bonferroni test and two-way ANOVA (Fig.1A). In the case of $S$. aureus, only a concentration of $120 \mu \mathrm{L} / \mathrm{mL}$ of oil 2 significantly inhibited microbial growth (Fig.1B). Oils 1 and 3 did not form a halo larger than those observed for the control groups (Fig.1B). For Salmonella cholerasuis all the tested concentrations $(30,60$ and $120 \mu \mathrm{L} / \mathrm{mL})$ of all oils tested $(1,2$ and 3$)$ significantly inhibited the growth of this microorganism, suggesting that a low concentration of. L. origanoides oil can inhibit the growth of Salmonella cholerasuis (Fig.1C).

The results of the MIC and MBC tests indicate that 120 $\mu \mathrm{L} / \mathrm{mL}$ of all of the oils tested inhibited microbial growth. A concentration of $60 \mu \mathrm{L} / \mathrm{mL}$ inhibited the growth of $E$. coli with all three oils and of $S$. aureus with oil two. A concentration of $120 \mu \mathrm{L} / \mathrm{mL}$ is enough to cause death of the microorganisms.

With regard to acute oral toxicity, the animals did not show any changes in locomotion, behavior, respiration, skin, or fur. The animals were stables throughout the entire treatment. There was no significant difference in weight of the animals during the experiment (Fig.2A). Macroscopic analyses of tissues showed that no organs (heart, liver, kidney) from the groups treated with L. origanoides showed
A)

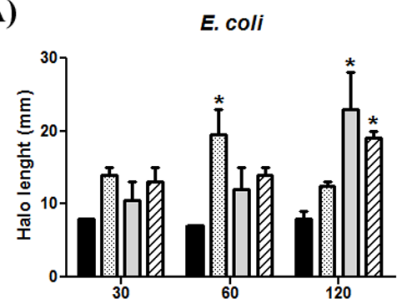

B)

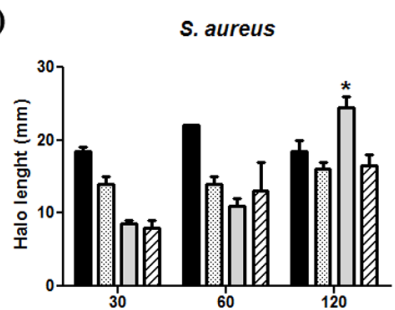

C)

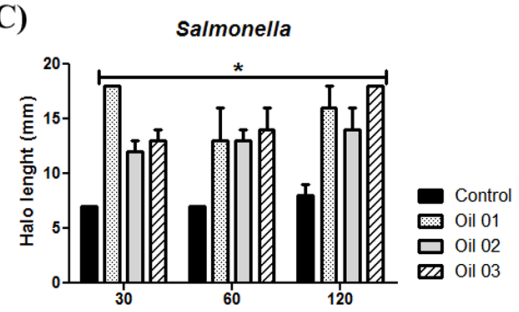

Fig.1. Sensitivity test of three batches of Lippia origanoides oil against different microorganisms. (A) Escherichia coli, (B) Staphylococcus aureus, and (C) Salmonella spp. Oil 1 extracted in December 2011. Oil 2 extracted in May 2012. Oil 3 extracted in March 2012. Asterisk $\left({ }^{*}\right)$ indicates a significant difference between treatments $(\mathrm{p}<0.01)$.

A)

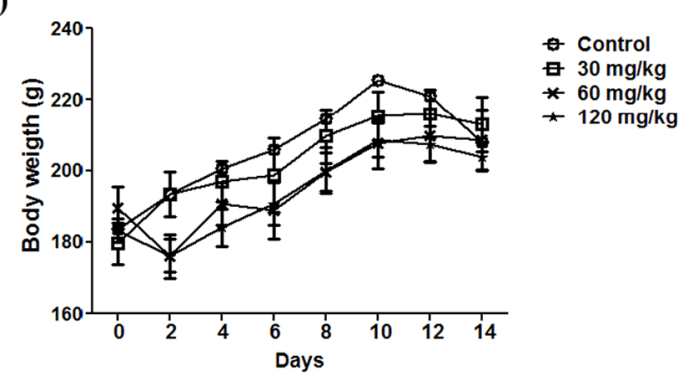

B)

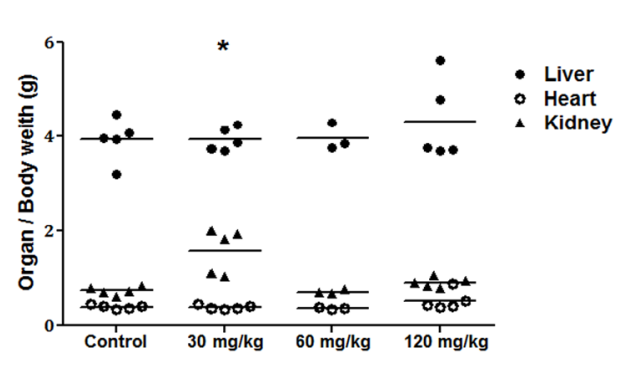

Fig.2. Change in weight of animals and organs. (A) Weight of animals in control group and those treated with different doses of Lippia origanoides essential oil. The values represent the weights measured in rats over 14 days after a single dose treatment. (B) Weight of organs expressed as percentage (\%) total weight of animals. Experimental group with $n=5$ animals. Asterisk $(*)$ indicates a significant difference between treatments $(\mathrm{p}<0.001)$. 
any morphological changes and their weights also did not significantly differ between the treatments and the control (Fig.2B).

The hematological parameters of animals treated with L. origanoides oil in the acute toxicity study were within the reference limits. There were no significant differences in the full hematological analysis (leukocytes, red cells, eosinophils, lymphocytes and basophils, hemoglobin, hematocrits and platelets). Biochemical analysis of blood taken from animals treated with L. origanoides oil showed that there was an alteration only in the enzyme, glutamic oxaloacetic transaminase (AST) in animals treated with $60 \mathrm{mg}$ / $\mathrm{kg}$ of $L$. origanoides oil, indicating a possible hepatic alteration in the animals of this group (Table 2).

Histopathological studies on the liver, heart, and kidneys were performed to determine the presence of pathological alterations caused by the L. origanoides oil. The results indicate that there was no dose-dependent histopathological alteration in the organs from the treated groups compared with the control (Fig.3).

During the study assessing the chronic toxicity of L. origanoides oil, there were no changes in behavior or body weight of the animals throughout the experiment (Fig.4A). There were no significant changes in the weight of the organs (expressed as percentage of total body weight) in treated animals when compared to the control group (Fig.4B).

The hematological and biochemical parameters measured to assess the chronic toxicity are described in Table 3.

Table 2. Biochemical parameters of Wistar rats treated with a single oral dose of Lippia origanoides essential oils

\begin{tabular}{lcccc}
\hline Parameter & Control & $30 \mathrm{mg} / \mathrm{kg}$ & $60 \mathrm{mg} / \mathrm{kg}$ & $120 \mathrm{mg} / \mathrm{kg}$ \\
\hline TGP (ALT) & $98.66 \pm 12.73$ & $77.6 \pm 3.81$ & $82 \pm 6.81$ & $75.4 \pm 8.47$ \\
TGO (AST) & $103.66 \pm 46.27$ & $185 \pm 42.78$ & $248.75 \pm 83.97^{\mathrm{a}}$ & $196.2 \pm 11.15$ \\
Urea & $62 \pm 8.00$ & $47.4 \pm 2.94$ & $53.25 \pm 2.78$ & $49.6 \pm 2.42$ \\
Creatinine & $0.51 \pm 0.06$ & $0.47 \pm 0.03$ & $0.57 \pm 0.02$ & $0.45 \pm 0.07$
\end{tabular}

Biochemical parameters obtained from the serum of animals, treated a single dose of an oral vehicle (Control, $\mathrm{n}=5$ ) or a single oral dose of Lippia origanoides essential oils at doses of 30,60 and $120 \mathrm{mg} / \mathrm{kg}(\mathrm{n}=5)$. The values represent the mean \pm standard deviation. Statistical comparisons of the experimental animals with the control group were performed using analysis of variance (ANOVA) and Bonferroni post-tests. $\mathrm{n}=$ represents the number of animals in each group. $\mathrm{a}=$ represents a significant difference when compared with the control $(\mathrm{p}<0.001)$.

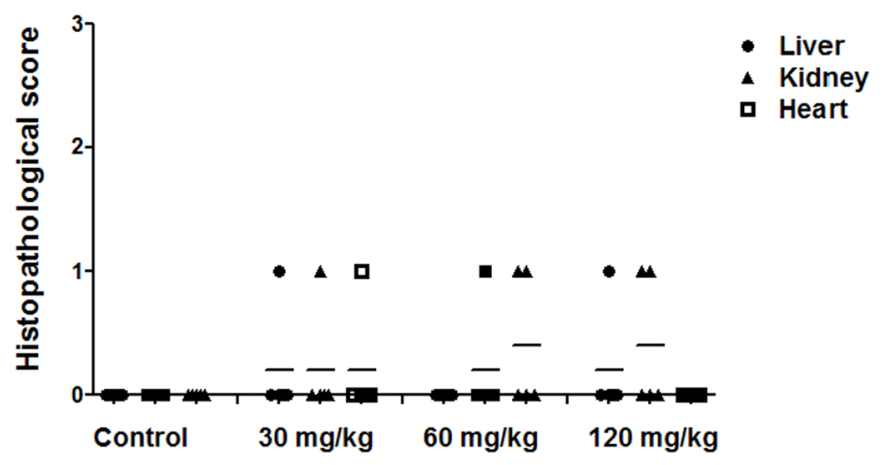

Fig.3. Histopathological analysis of the acute toxicity of Lippia origanoides oil. Animals were treated with 30,60 or $120 \mathrm{mg} /$ $\mathrm{kg}$ administered orally for 14 days. Assessment score used for analysis: $0=$ no damage, $1=$ discrete damage, $2=$ moderate damage, 3 = severe damage. The statistical analysis performed was the non-parametric Kruskal-Wallis test with Dunn's multiple comparison test $(\mathrm{p}<0.0005)$.

There was a significant change in mean corpuscular volume (MCV), which is the index that helps determine the size of erythrocytes in the diagnosis of anemia and in mean corpuscular hemoglobin $(\mathrm{MCH})$ which represents the weight of hemoglobin in the erythrocyte (Table 3).

Plasma levels of AST, ALT, urea and creatinine were measured after 15 or 30 days of dosing with the L. origanoides oil. These values did not differ significantly when compared to the control group suggesting that there was no hepatotoxic or nephrotoxic effects on the animals (Table 3).

Histopathological analyses of the liver, heart, and kidneys did not show significant abnormalities (Fig.5A). Together, these data suggest that the L. origanoides essential oil does not have toxic effects when administered at a concentration of $120 \mathrm{mg} / \mathrm{kg}$ for a period of 30 days.

\section{DISCUSSION}

The essential oils of medicinal plants are typically a complex mixture of chemical compounds (primarily terpenes) which can act individually, additively or synergistically to improve health. As well as being used as therapeutic agents, bioactive substances isolated from the essential oils of plants may be used as prototype molecules for new synthetic compounds and as tools in physiological studies.

B)

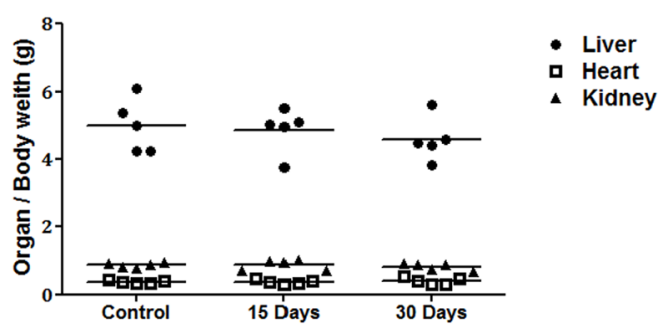

Days

Fig.4. Change in animals and organs weight. (A) Weight of animals in control group and those treated with $120 \mathrm{mg} /$ $\mathrm{kg}$ of Lippia origanoides essential oil. The values represent the weights measured in rats over 30 days of treatment. (B) Weight of organs expressed as percentage (\%) total weight of animals. Experimental group with $n=5$ animals $(\mathrm{p}<0.001)$.

Pesq. Vet. Bras. 34(12):1153-1161, dezembro 2014 
Table 3. Hematological and biochemical parameters of Wistar rats treated with oral doses of $120 \mathrm{mg} / \mathrm{kg} \mathrm{of} \mathrm{Lippia}$ origanoides essential oils for $\mathbf{3 0}$ days

\begin{tabular}{|c|c|c|c|c|c|c|c|}
\hline \multicolumn{4}{|c|}{ Hematological data } & \multicolumn{4}{|c|}{ Biochemical data } \\
\hline Parameter & Control & Lippia origanoides & Lippia origanoides & Parameter & Control & Lippia origanoides & Lippia origanoides \\
\hline & & (15 days) & (30 days) & & & (15 days) & (30 days) \\
\hline Erythrocyte $\left(\mathrm{mm}^{3}\right)$ & $7.23 \pm 0.03$ & $6.90 \pm 1.59$ & $7.90 \pm 0.45$ & TGP (ALT) & $84 \pm 13.93$ & $154 \pm 97.14$ & $76.5 \pm 9.71$ \\
\hline Hemoglobin (g/dL) & $15.49 \pm 1.10$ & $13.23 \pm 2.87$ & $14.87 \pm 0.68$ & TGO (AST) & $251.3 \pm 137.6$ & $6 \quad 167.7 \pm 93.88$ & $133.8 \pm 62.46$ \\
\hline Hematocrit (\%) & $44.1 \pm 0.7$ & $38.63 \pm 8.96$ & $43.15 \pm 2.19$ & Urea & $60.5 \pm 7.76$ & $60 \pm 9.16$ & $40.75 \pm 6.34$ \\
\hline MCV (fL) & $61 \pm 1.22$ & $56.01 \pm 2.45 a$ & $54.59 \pm 0.81 \mathrm{a}$ & Creatinine & $0.35 \pm 014$ & $0.52 \pm 0.29$ & $0.33 \pm 0.06$ \\
\hline $\mathrm{MCH}(\mathrm{pg})$ & $21.43 \pm 0.23$ & $19.26 \pm 1.27 b$ & $18.82 \pm 0.26 b$ & & & & \\
\hline $\mathrm{MCHC}(\mathrm{g} / \mathrm{dL})$ & $35.14 \pm 0.32$ & $34.37 \pm 0.96$ & $34.48 \pm 0.39$ & & & & \\
\hline Platelets $\left(\mathrm{mm}^{3}\right)$ & $613500 \pm 95500$ & $277933 \pm 220468$ & $449377 \pm 304037$ & & & & \\
\hline Leukocytes $\left(\mathrm{mm}^{3}\right)$ & $734 \pm 240$ & $10417 \pm 3579$ & $9900 \pm 6532$ & & & & \\
\hline
\end{tabular}

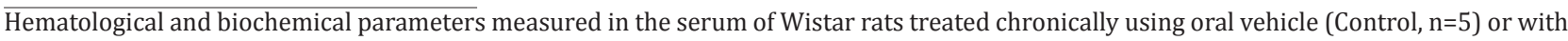
daily doses of $120 \mathrm{mg} / \mathrm{kg}$ of Lippia origanoides essential oil $(\mathrm{n}=5)$ for 30 days. The values represent the mean \pm standard deviation. Statistical comparisons of the experimental animals with the control group were performed using analysis of variance (ANOVA) and Bonferroni post-tests. $n=$ represents the number of animals in each group. The letters a $(\mathrm{p}<0.0028)$ and $b(\mathrm{p}<0.0114)$ represent a significant difference when compared with the control.

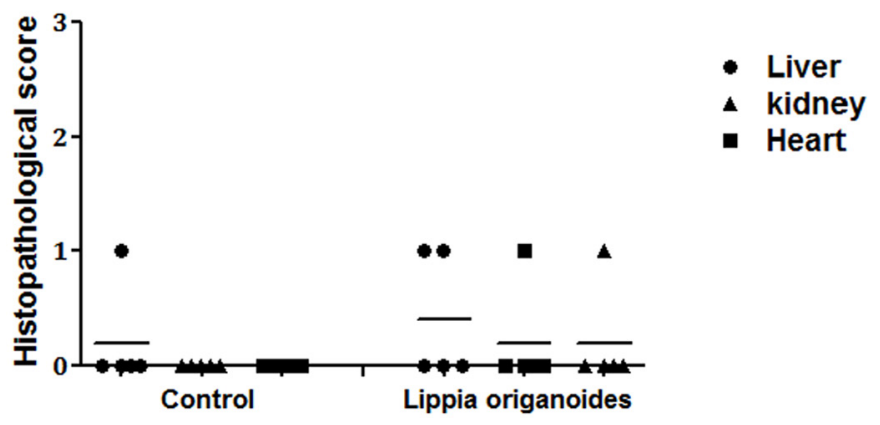

Fig.5. Histopathological analysis of the chronic toxicity of Lippia origanoides oil. Histopathological results of animals treated with $120 \mathrm{mg} / \mathrm{kg}$ for 30 days. Assessment score used for analysis: $0=$ no damage, $1=$ discrete damage, 2 = moderate damage, 3 = severe damage. The statistical analysis performed was the non-parametric Kruskal-Wallis test with Dunn's multiple comparison test $(\mathrm{p}<0.0005)$.

Thymol and carvacrol are monoterpenoid phenols biosynthesized in plants from g-terpinene and $p$-cymene (Baser \& Demirci 2007, Lopez et al. 2011). Therefore, these precursors are always present in essential oils that contain thymol and carvacrol. In addition, other biosynthesized intermediates may also be present, such as terpinen-4-ol, cumin alcohol, and $p$-cymen-8-o l (Baser \& Demirci 2007).

Previous studies have shown that the essential oil of native specimens of L. origanoides from the North East of Brazil is composed of approximately $60 \%$ thymol (Fontenelle et al. 2007). Carvacrol, an optical isomer of thymol, is also found in the essential oil of Origanum vulgare (Tian \& Lai 2006) making up more than $92 \%$ of its essential oils.

In this study, lower concentrations of thymol and carvacrol were found in the L. origanoides oil compared to concentrations described in the literature. However, the effects against the tested microorganisms showed that, even in lower concentrations, o-thymol and carvacrol could inhibit microbial growth (Fig.1).

Also in this study, a much higher concentration of o-cymene was observed (approx.25\%, Table 1). Although this compound is a biological precursor of carvacrol, no bactericidal activity has been described for this compound o-cymene. However, studies on p-cymene, an isomer of o-cymene, indicate that while it is not effectively bactericidal when used alone, but when combined with carvacrol, it is quite effective against Bacillus cereus in vitro (Cimanga et al. 2002). This effect may be because p-cymene becomes incorporated in the lipid bilayer of Bacillus cereus, facilitating the transport of carvacrol through the plasma membrane (Cimanga et al. 2002). It is possible that the observation of bactericidal effect of Lippia origanoides oil in this study was due o-cymene, which was found in high concentrations in this preparation, may have acted in combination with thymol and carvacrol inducing inhibition growth of microorganism (Fig.1).

The variation in the proportions of the active compounds between oils used in different studies may be explained based in period of collect of plants. Its know that time of the year when the aerial parts were collected to extract the oils can influence the concentrations of compounds. Factors such as temperature, relative humidity, sun and wind exposure may directly influence the chemical composition of essential oils (Simões \& Spitzer 2004). The quantities of chemical components in the essential oils may vary according to the stage of development of the plant (Simões \& Spitzer 2004) and different period of the year (Santos et al. 2009). Plants are richer in essential oils when the weather is stable, warm, sunny which are the best conditions for harvesting. There was no significant difference in the relative quantity of compounds in the three batches of oils used in this study, despite having been collected at different times of the year (Table 1 ).

Morais (2009) suggested that genetic factors, age of the plant and climatic and environmental factors, as well as the period of the year the plants were collected, may cause significant alterations in the production of secondary metabolites influencing the composition of essential oils and thereby the oil's antimicrobial effect. According to Costa et al. (2011), the essential oil of L. origanoides inhibited the growth of $S$. aureus and E. coli with inhibition halos of 8.2 and $23.2 \mathrm{~mm}$ respectively at a concentration of $160 \mu \mathrm{L} / \mathrm{mL}$.

Klancnik et al. (2010) tested different essential oils against different bacteria and concluded that despite diffe- 
rent mechanisms of action, in general, essential oils have greater effectiveness against gram-positive bacteria. Klancnik et al. (2010) present data that indicate that the main reason for differences in bacterial susceptibility may be due to the external membrane that covers the cell wall of gram-negative bacteria, which limits the diffusion of compounds through the lipopolysaccharide cell wall. Other authors have speculated whether differences in sensitivity of essential oils described in the literature are also associated with differences in methodology, including the method of extraction (Othman et al. 2011, Radulovic et al. 2013). Also, antimicrobial activity may be dependent on the site of action in the cell may potentiate these differences in activity (Negi 2012).

The results obtained here indicate that the concentration of $120 \mu \mathrm{l} / \mathrm{mL}$ of $L$. origanoides oil inhibited the growth of the tested microorganisms. This concentration proved to be effective in all tests, suggesting that this is an effective concentration for antimicrobial use. Our results are in agreement with data in the literature, which show the bactericidal activity of the L. origanoides essential oil against various microorganisms (Veras et al. 2014) and suggests that this concentration is most efficient in oils obtained from plants collected between the months of December and May. The results obtained in other studies using the essential oil of $L$. origanoides extracted from plants from the North of Minas Gerais also concur with the optimal concentration found in this study (Castro et al. 2011, Costa et al. 2011, Pinho et al. 2012).

The acute toxicity test data indicate that Wistar rats treated with L. origanoides oil showed normal behavior and physiology in all treatment groups. The lack of organ damage in the histopathological analyses suggests that there were no toxic effects from the L. origanoides oil. The hematological parameters were within the reference limits, suggesting that there were no significant effects of the $L$. origanoides oil treatments when compared to the control. Histopathological studies of the liver, heart, and kidneys showed no significant dose-dependent histopathological alterations in the treated groups compared to the control (Fig.3). These suggest that oral administration of L. origanoide soil for 14 consecutive days, at the doses used in this study was not toxic.

Studies in literature about effect of acute toxicity of $L$. origanoides essential oil are scarce but was demonstrated that Lippia sidoides extract, administrated by intraperitoneal way, has a DL50 of $1329,17 \mathrm{mg} / \mathrm{kg}$ that was considered of high toxicity (Almeida et al. 2010). This result is different from showed in this work, but is important highlight that methods and protocols was distinct of those presented in this study.

Our studies are consistent and can be confirmed by serum biochemical analyses that showed no alteration in the serum levels of the enzyme, glutamic oxaloacetic transaminase (AST). In only one of the dose groups $(60 \mathrm{mg} / \mathrm{kg}$ L. origanoides oil) there was alteration that may indicate hepatic toxicity in the animals of this group (Table 2). However, other analyses performed to investigate hepatic changes do not suggest that this isolated result is due to treatment with L. origanoides oil. Since this enzyme, AST, is found in high concentrations in the cytoplasm and mitochondria of hepatocytes, skeletal and cardiac muscles, and is also found in the kidney, pancreas and erythrocytes, damage to any of these organs could increase the levels of this enzyme in the blood. Because there is no laboratory technique to determine the origin of AST found in the blood, damage to any of these organs is a possible source of increased serum AST (Lehninger et al. 2005).

In this study, no damage to any of these organs, kidney, liver and heart, was observed that could explain the alteration in AST in the $60 \mathrm{mg} / \mathrm{kg}$ group. These organs were chosen because they are the common target organs of toxic agents. These data are in agreement with data in the literature, where other studies have shown no cell damage in these tissues in tests assessing the toxicity of L. origanoides and/or its components. Studies with Phyllanthus emblica Linn. plants demonstrated that alterations in weigh organs is frequently but this alterations not causes change in macroscopic or microscopic changes were detected in the internal organs or tissues in any of the treatment rats (Jaijoy et al. 2010).

The results of the chronic toxicity test showed no evidence of chronic toxicity under the conditions in this study. During the study, no changes in behavior or body weight were observed in the treated animals compared to control animals (Fig.4A). The animals were weighed on alternate days and no weight loss was recorded during treatment. There was also no significant alteration in heart, kidney, or lung organ weight (expressed as percentage of total body weight) observed in the treated animals when compared to the control group (Fig.4B).

The hematological and biochemical parameters measured to assess the chronic toxicity are described in Table 3. A significant decrease was observed in the mean corpuscular volume (MCV) which is the index that helps to determine the size of erythrocytes. A decrease was also observed in mean corpuscular hemoglobin ( $\mathrm{MCH}$ ) which represents the amount of hemoglobin in the erythrocytes (Table 3). These parameters are below the levels for the control animals and beyond the reference range for Wistar rats (Dantas et al. 2006, Castello-Branco et al. 2011) and may indicate some interference in erythropoiesis.

No alterations were seen in the serum measurements of AST, ALT, urea and creatinine after 15 or 30 days of dosing with L. origanoides oil. This suggests that there was no toxic effect of oral L. origanoides oil in these rats (Table 3). The histopathological analyses of the liver, heart and kidneys did not show any significant abnormalities (Fig. 5). As AST and ALT are considered sensitive indicator of hepatic damage and into the limits can provide a qualitative evaluation of damage degree suffering by hepatocytes (Martin et al. 1981) this result suggest that no alterations in liver was observed after treatment with L. organoides oil. The use of this oil cannot be hepatotoxic, when used in doses tested.

Few toxicity studies on L. origanoides oil or the compounds thymol and carvacrol are sparse have been reported in the literature. However, the results in this study are 
in agreement with the results described by Fontenelle et al. (2007) and Almeida et al. (2010) despite a difference in methodology.

A recent study by Ferraz et al. (2013) showed the potential activity of thymol, present in plants of the genus Lippia, in tumor cells, indicating other important prospects for medicinal use. Cleff et al. (2008) described the lack of toxicity of repeated doses of Ocimum gratissimum (administered orally and intravaginally in rats) which like L. origanoides, has considerable quantities of thymol and carvacrol. However, Cabello et al. (2014) who analyzed the effect of thymol and carvacrol in human CACO-2 cells, observed dose and time dependent effects including lipid degeneration, mitochondrial damage, nucleolar segregation and apoptosis.

Together these data suggest that the essential oil of L. origanoides does not cause any significant toxic effects when administered at a concentration of $120 \mathrm{mg} / \mathrm{kg}$ under the conditions of this study.

Using natural products derived from plants is becoming increasingly common worldwide and research to identify the beneficial effects and the possible adverse effects of their use, is becoming increasingly important, especially studies that take into account the effects of these products at the molecular level.

\section{CONCLUSIONS}

The essential oil of Lippia origanoides has potential as an antimicrobial, according to the sensitivity tests in the present study.

This extract showed no acute or chronic toxicity in rats, as confirmed by no change in the body weight of the treated animals compared to controls and no significant changes in the levels of metabolic in serum.

A detailed assessment of hematological, biochemical and histopathological effects of L. origanoides oil did not indicate any significant changes in physiological functions or organ function in animals treated with L. origanoides oil.

Based on these findings, this essential oil may have practical application as a veterinary antimicrobial. Further exploration of this medicinal plant for veterinary phytotherapy is warranted.

Acknowledgements.- We would like to thank everyone who contributed to this study with financial support from the agencies FAPEMIG (Fundação de Amparo à Pesquisa do Estado de Minas Gerais, Brazil), CNPq (Conselho Nacional de Desenvolvimento Científico e Tecnológico, Brazil), CAPES (Coordenação de Aperfeiçoamento de Pessoal de Nível Superior, Brazil), and Pró-Reitoria de Pesquisa of UFMG (PRPq/UFMG).

\section{REFERENCES}

Almeida A.C., Sobrinho E.M., Pinho L., Souza P.N.S., Martins E.R., Duarte E.R., Santos H.O., Brandi I.V., Cangussu A.S. \& Costa J.P.R. 2010. Toxicidade aguda de extratos hidroalcoólicos de folhas de alecrim-pimenta, barbatimão, aroeira e farelo da casca de pequi administrados intraperitonealmente. Ciência Rural 40(1). Disponível em <http://www.scielo. $\mathrm{br} / \mathrm{pdf} / \mathrm{cr} / \mathrm{v} 40 \mathrm{n} 1 / \mathrm{a} 415 \mathrm{cr} 1346 . p d f>$ Access in March 2014.

Baser K.H.C. \& Demirci F. 2007. Chemistry of essential oils, p.43-86. In: Berger R.G. (Ed.), Flavors and Fragrances: chemistry, bioprospecting and sustainability. Springer, Heidelberg.
Brasil 2006. Decreto no 5813, de 22 de junho de 2006. Aprova a Política Nacional de Plantas Medicinais e Fitoterápicos e dá outras providências. Agência Nacional de Vigilância Sanitária, Ministério da Saúde, Brasília, DF. Disponível em <http://bvsms.saude.gov.br/bvs/publicacoes/politica_nacional_fitoterapicos.pdf $>$ Acessado em junho de 2013.

Cabello M.R.L., Praena D.G., Pichardo Moreno F.J., Bermúdez J.M., Aucejo S. \& Cameán A.M. 2014. Cytotoxicity and morphological effects induced by carvacrol and thymol on the human cell line Caco-2. Food Chem. Toxicol. 64:281-290.

Castello-Branco A.C.S., Diniz M.F.F.M., Almeida R.N., Santos H.B., Oliveira K.M., Ramalho J.A. \& Dantas J.G. 2011. Biochemical and hematological parameters of Wistar rat and Swiss mice in the Professor Thomas George Animal Laboratory. Revta Bras. Ciênc. Saúde 15:209-214.

Castro C.E., Ribeiro J.M., Diniz T.T., Almeida A.C., Ferreira L.C., Martins E.R. \& Duarte E.R. 2011. Antimicrobial activity of Lippia sidoides Cham. (Verbenaceae) essential oil against Staphylococcus aureus and Escherichia coli. Revta Bras. Pl. Med. 13:293-297.

Cimanga K., Kambu K., Tona L., Apers S., De Bruyne T., Hermans N., Totte J., Pieters L. \& Vlietinck A.J. 2002. Correlation between chemical composition and antibacterial activity of essential oils of some aromatic medicinal plants growing in the Democratic Republic of Congo. J. Ethnopharmacol. 79:213-220.

Cleff M.B., Meinerz A.R., Sallis E.S., Antunes T.A., Mattei A., Rodrigues M.R., Meireles M.C.A. \& Braga J.R.M. 2008. Toxicidade pré-clínica em doses repetidas do óleo essencial de Origanum vulgare L. (Orégano) em ratas Wistar. Lat. Am. J. Pharm. 27:704-709.

Costa J.P.R., Almeida A.C., Martins E.R., Rodrigues M.N., Santos C.A. \& Menezes I.R. 2011. Atividade antimicrobiana do óleo essencial de alecrim-pimenta e do extrato bruto seco do barbatimão diante de bactérias isoladas do leite. Biotemas 24:1-6.

Dantas J.A., Ambiel C.R., Cuman R.K.N., Baroni S., Bersani A. \& Ciomar A. 2006. Valores de referência de alguns parâmetros fisiológicos de ratos do Biotério Central da Universidade Estadual de Maringá, Estado do Paraná. Acta Scient. Health Sci. 28:165-70.

Falkenberg M.B., Santos R.I. \& Simões C.M.O. 2007. Introdução à análise fitoquímica, p.229-245. In: Simões C.M.O. (Ed.), Farmacognosia da Planta ao Medicamento. 6 ${ }^{\mathrm{a}}$ ed. Editora da UFRGS, Porto Alegre/RS, Editora da UFSC, Florianópolis/SC.

Ferraz R.P.C., Bomfin D.S., Carvalho N.C., Soares M.B.P., Silva T.B., Machado W.J., Prata A.P.N., Costa E.V., Moraes V.R.S., Nogueira P.C.L. \& Bezerra D.P. 2013. Cytotoxic effect of leaf essential oil of Lippia gracilis Schauer (Verbenaceae). Phytomedicine 20:615-621.

Fontenelle R.O.S., Morais S.M., Britol E.H.S., Kerntopf M.R., Brilhante R.S.N., Cordeiro R.A., Tome A.R., Queiroz M.G.R., Nascimento N.R.F., Sidrim J.J.C. \& Rocha M.F.G. 2007. Chemical composition, toxicological aspects and antifungal activity of essential oil from Lippia sidoides. Cham. J. Antimicrob. Chemother. 59:934-940.

Gatyas G. \& Savage C. 2010. IMS Forecasts Global Pharmaceutical Market Growth of 5-8\% annually through 2014: maintains expectations of 4-6\% growth in 2010. IMS Health Incorporated, NORWALK, CT. Disponível em <http://www.imshealth.com/portal/site/imshealth> Accessed in Jan. 2014.

Jaijoy K., Soonthornchareonnon N., Lertprasertsuke N., Panthong A. \& Sireeratawong S. 2010. Acute and chronic oral toxicity of standardized water extract from the fruit of Phyllanthus emblica Linn. Int. J. Appl. Res. Nat. Prod. 3(1):48-58.

Klančnik A., Piskernik S., Jeršek B. \& Možina S.S. 2010. Evaluation of diffusion and dilution methods to determine the antibacterial activity of plant extracts. J. Microbiol. Methods 81:121-126.

Lehninger A.L., Nelson D.L. \& Cox M.M. 2005. Principles of Biochemistry. $4^{\text {th }}$ ed. Freeman and Company, New York.

Lopez M.A., Stashenko E.E. \& Fuentes J.L. 2011.Chemical composition and antigenotoxic properties of Lippia alba essential oils. Genet. Mol. Biol. 34:479-488.

Malone M.H. \& Robichaud R.C.A. 1962. Hippocratic screen for pure or crude drug materials. Lloydia 25:320-332. 
Martin D.W., Mayes P.A., Rodwell Y.W. \& Harper S. 1981. Review of Biochemistry. Lange Medical, California. 688p.

Matos F.J.A. 2002. Farmácias Vivas. 4⿳亠丷a ed. EUFC, Fortaleza.

Morais L.A.S. 2009. Influência dos fatores abióticos na composição química dos óleos essenciais. Horticult. Bras. 27:4050-4063.

Negi P.S. 2012. Plant extracts for the control of bacterial growth: efficacy, stability and safety issues for food application.Int. J. Food Microbiol. 156:7-17.

Pinho L., Souza P.N.S., Macedo Sobrinho E., Almeida A.C. \& Martins E.R. 2012. Atividade antimicrobiana de extratos hidroalcoólicos das folhas de alecrim-pimenta, aroeira, barbatimão, ervabaleeira e do farelo da casca de pequi. Ciência Rural 42:326-331.

OECD 2001. Test no.420: Acute Oral Toxicity: acute toxic class method. OECD Guidelines for the Testing of Chemicals, Health Effects, 17 Dez. 2001.

Oliveira F.P., Lima E.O., Siqueira Júnior J.P., Souza E.L., Santos B.H.C. \& Barreto H.M. 2006a. Effectiveness of Lippia sidoides Cham. (Verbenaceae) essential oil in inhibiting the growth of Staphylococcus aureus strains isolated from clinical material. Revta Bras. Farmacognosia 16:510-516.

Oliveira P.F., Lima O.E. \& Júnior S.P.J. 2006b. Effectiveness of Lippia sidoides Cham. (Verbenaceae) essential oil inhibiting the growth of Staphylococcus aureus strains isolated from clinical material. Braz. J. Pharmacognosy $16: 510-516$.

Othman M., Loh H.S., Wiart C., Khoo T.J., Lim K.H. \& Ting K.N. 2011. Optimal methods for evaluating ntimicrobial activities from plant extracts. J. Microbiol. Methods 84:161-166.
Pinto T.J.A., Kaneko T.M. \& Ohara M.T. 2003. Controle Biológico de Qualidade de Pprodutos Farmacêuticos, Correlatos e Cosméticos. $2^{\underline{a}}$ ed. Atheneu, São Paulo.

Radulović N.S., Mladenović M.Z., Blagojević P.D., Stojanović-Radić Z.Z., Ilic-Tomic T., Senerovic L. \& Nikodinovic-Runic J. 2013. Toxic essential oils. III. Identification and biological activity of new allylmethoxyphenyl esters from a Chamomile species (Anthemis segetalis Ten.). Food Chem. Toxicol. 62:554-565.

Rios J.L., Recio M.C. \& Villar A. 1988. Screeening methods for natural products with antimicrobial activity: review of the literature. J. Etnopharmacol. 23:127-149.

Santos A., Paduan R.H., Gazin Z.C., D’Oliveira J.E., Pérsio S., Cortez D.A.G., \& Cortez L.E.R. 2009. Determinação do rendimento e atividade antimicrobiana do óleo essencial de Cymbopogon citratus (DC.) Stapf em função de sazonalidade e consorciamento. Revta Bras. Farmacognosia, 19:436441.

Simões C.M.O. \& Spitzer V. 2004. Óleos voláteis, p.467-496. In: Simões C.M.O., Schenkel E.P., Gosmann G., Mello J.C.P., Mentz L.A. \& Petrovick R. (Eds), Farmacognosia: da planta ao medicamento. 5a ed. UFRGS, Porto Alegre.

Tian H. \& Lai D.M. 2006. Analysis on the volatile oil in Origanum vulgare. Zhongyaocai, 29:920-921.

Veras H.N.H., Rodrigues F.F.G., Botelho M.A., Menezes I.R.A., Coutinho H.D.M. \& Costa G.M. 2014. Antimicrobial effect of Lippia sidoides and thymol on Enterococcus faecalis biofilm of the bacterium isolated from root canals. Scient. World J. 14:1-6. 